\title{
Introduction to Part II of the Special Issue: Design, Development and Implementation of Electronic Learning Environments for Collaborative Learning
}

\section{Paul A. Kirschner}

Development in society and business, and related changes in higher education and lifelong learning require educators and educational designers/technologists to rethink education. Examples of such changes are the growing importance of achieving complex learning, the integration of learning and work in education, and the need for improved flexibility with regard to time, place and individual needs. These changes cannot simply be responded to by adding technological solutions implemented according to existing educational approaches. Instead, an integrated view on e-learning is necessary, characterized by the combination of pedagogical, technical, social, and organizational factors. The final four articles this special issue (which began with articles on the design of and educational approaches in electronic collaborative learning environments and the role of authenticity in learning and assessment, in the previous number: Gulikers, 2004; Kirschner, 2004; Kirschner, Strijbos, Kreijns, \& Beers, 2004) discuss a theoretical basis for collaborative learning in work-based settings and present different aspects of a research and design agenda for online collaborative learning.

In this number, Collis and Margaryan take elearning from the traditional school setting to the corporate setting. In their article they show how collaborative learning can take on special forms in the on-going professional development of engineers in a multinational corporation as a tool for capturing experience, reusing it, and creating new artifacts and solutions for workplace applications. Reeves, Herrington, and Oliver present a research agenda for collaborative learning. In their view traditional "basic to applied" research methods have provided an insufficient basis for advancing the design and implementation of advanced collaborative learning environments. Instead, most of the significant progress that has been made has been accomplished through development research, design experiments, or formative research. Elen, the first discussant in this special issue, introduces the notion of instructional design anchor points (IDAPs) as the basis for instructional design, arguing that research on IDAPs can become more useful and influential when it meets certain conditions. Finally, Wilson offers an activity-based perspective on E-learning environments, resulting in a flexible stance toward instructional strategies, artifact design, emergent activity, and learning outcomes.

Paul A. Kirschner [paul.kirschner@ou.nl] is with the Educational Technology Expertise Center, Open University of the Netherlands, P.O. Box 2960, 6401 DL Heerlen, The Netherlands. Voice: +31 45 5762361; Fax: +31 455762901 .

\section{REFERENCES}

Gulikers, J. T. M., Bastiaens, T. J., \& Kirschner, P. A. (2004). A five-dimensional framework for authentic assessment, Educational Technology Research and Development, 52(3), 67-86.

Kirschner, P. Introduction to Part I of two-part special issue: Design, development, and implementation of electronic learning environments for collaborative learning, Educational Technology Research and Development, 52(3), 39-46.

Kirschner, P., Strijbos, J.-W., Kreijns, K., \& Beers, P. J. (2004). Designing electronic collaborative learning environments, Educational Technology Research and Development, 52(3), 47-66. 
Copyright of Educational Technology Research \& Development is the property of Association for Educational Communications \& Technology and its content may not be copied or emailed to multiple sites or posted to a listserv without the copyright holder's express written permission. However, users may print, download, or email articles for individual use. 